\title{
Dismantling, Reorganization, and Creation: The Introduction to Ethnology Museums: Culture, Politics, and Institutional Change*
}

\author{
Camille Mazé, Frédéric Poulard, and Christelle Ventura
}

\begin{abstract}
This contribution originally appeared in French as the introduction to the edited volume Les musées d'ethnologie: culture, politique et changement institutionnel. It offers a historical and contemporary account of cultural, political, and institutional factors that have reshaped museum anthropology and museums of anthropology in France since the rise of the field and its institutions in the 19th century.
\end{abstract}

[Keywords: social history; intellectual history; anthropological museums; ethnological museums; folk museums; history of science; history of anthropology; governance; history of anthropology; France; Europe. Keywords in italics are derived from the American Folklore Society Ethnographic Thesaurus, a standard nomenclature for the ethnographic disciplines.]

As cultural and scientific institutions very closely linked to the political sphere, ethnology museums have been experiencing a wave of transformation since the early 1990s, affecting both national and regional structures. Dedicated to the representation of culture, be it home, neighboring, or distant, ethnology museums were a 19th century phenomenon in most European countries. For some observers, such institutions are now obsolete. Notable examples in France include the Musée de l'Homme anthropology museum and the Musée National des Arts et Traditions Populaires (MNATP, the National Museum of Popular Arts and Traditions). Many countries are today undertaking reorganization plans, with collections being transferred and institutions being dismantled, closed or moved, reopened or created; all of which profoundly change the landscape of ethnology museums. Through the new model of museums that are fully in line with current post-colonialism, Europeanization, or globalization processes, countries seek to offer a broader view of "identity," no longer strictly local or national, but rather cross-cultural and cosmopolitan. Renovated in the early 1980s, the Museum of Ethnography of Neuchâtel, Switzerland, is considered a precursor of this post-colonial revival of so-called "exotic" museums. Other projects have emerged since then, more or less along the same lines. These include the Esplanade des Mondes ethnography museum in Geneva, abandoned in 2001; the National Museum of World Cultures in Gothenburg, opened in 2004; the Quai Branly Museum in Paris, opened in 2006; and the Musée des Confluences anthropology museum in Lyon, whose construction began in 2007. Museums of popular arts and traditions, folklore or Volkskunde, have also been transformed into museums dedicated to cultures or European civilization, as in

\footnotetext{
* This peer-reviewed contribution was accepted for publication in Museum Anthropology Review on August 1, 2014. The original French language work appeared in Les musées d'ethnologie: Culture, politique et changement institutionnel published and copyrighted in 2013 by Comité des travaux historiques et scientifiques. Assistance with the translation was provided by the Bureau de Traduction de l'Université at the Université de Bretagne Occidentale and financed by the Center of Breton and Celtic research (CRBC, Brest), the Laboratory of Anthropology and History of the Institution of Culture (Lahic-iiac, Paris), and the Center of Studies and Sociological and Economic Research (Clersé, Lille). The English version of the work is licensed under the Creative Commons Attribution 4.0 International License. To view a copy of this license, visit http://creativecommons.org/licenses/by/4.0/
} 
the case of the Museum of European Cultures (Museum Europäischer Kulturen) in Berlin. By trying to embody universalist ideology, the rhetoric of relativism, and the new cultural diversity standard, the goal of these projects is to combat ethnocentrism and to advocate cosmopolitanism.

This situation, which has led foreign researchers to talk of disruptions and transformations in the museum landscape (Rogan 2003; Lebovics 2004), is interpreted in France in terms of "crisis," feeding the conclusion frequently presented for the past thirty years or so (Baumann 2006) that there is a "decline in the institution" (Dubet 2002). ${ }^{1}$ The reasons put forward to explain this "crisis" within French ethnology museums are many and interlinked: budget crisis, due to their low funding (Querrien 1982; Héritier-Augé 1991), unlike art museums which are often better off; historical crisis, related to the bygone nature of these museums due to their dated collections and their difficulty collecting contemporary works (Le Menestrel 1996); political crisis, their history being reread through the prism of their links with nationalist ideologies since the 1930s (Faure 1989; Lebovics [1992] 1995; Boëll, Christophe, and Meyran 2009); epistemological crisis, marked by the gradual loss of interest on the part of academia and research for material culture and museum collections, which nevertheless formerly constituted a laboratory for experimentation (Davis 1999) and a major venue for the institutionalization of anthropology (Dias 1991; Segalen 1993; Jamin 1998); organizational crisis, illustrated by the internal difficulties in collaboration between researchers and curators (Dubuc 1998; Segalen 2005); and, finally, crisis of meaning for these institutions that are supposed to be, for their professionals, tools of vigilance, intellectual destabilization, and the fight against prejudice (Hainard and Kaehr 1985). These questions frequently give rise to debates and controversies, which are reported in the press. $^{2}$ Intellectuals, scientists, and political decision makers wonder about the past and future of these museums, listing the multiple reasons for this crisis or, more accurately, these crises. The community of ethnologists, notably, has become involved in the debate, bringing together both those who "militate" in favor of maintaining ethnology museums and their gradual evolution, and those who advocate radical change. ${ }^{3}$ The position of the governing bodies, sometimes brandishing this fact as a problem to be solved, must also be factored in.

Consequently, while marking off the real difficulties and challenges involved, the notion of crisis applied to ethnology museums is highly problematic. It notably places strong emphasis on the problems and inexorably refers to a prosperous past, which in comparison with the contemporary situation seems increasingly lackluster. It therefore exacerbates the contemporary break with the past to the detriment of a more detailed and contextual explanation of institutional change over the long term. It leaves unanswered a number of questions that are at the heart of this work. How do these museums adapt, or not, to their environment and its various political, professional, social, economic, and cultural components? What leeway and constraints do they have? What intermediaries are involved? In what ways do these factors affect the nature of the changes and how is institutional heritage managed? More generally, what can we learn from these phenomena of the contemporary relationships between culture and politics and the underlying institutional mechanisms?

The literature on folk museums does not completely ignore the issue of change. Three works, notably, deal specifically with this question, sometimes analyzing the relationship that these museums have maintained over time with regional development strategies (Chaumier 2003), and sometimes discussing our conceptions of otherness (L'Estoile 2007) or the politico- 
administrative framework and the transformation of cultural policies (Poulard 2010). Other recent works have taken a closer look at this issue of change, providing an analysis of identity and political strategies (Benoit 2002; Wahnich 2002; Ventura 2006; Mazé 2010). However, given the close link between these institutions and their political environment, to retain only the latter, it has to be said that the theme of change has not been very central. When dealt with, this question appears less as in-depth historical or socio-historical analyses of the institutions concerned, ${ }^{4}$ and more as questions and debates about their future, the latter falling within the register of normative assessments by readily expressing an opinion on what these museums should or should not be. ${ }^{5}$ In addition, in accordance with the recurring tendency of institutional approaches (Scott 2008), most of these works prefer analyzing the genesis of these institutions or the key stages in their development, to the detriment of their economic study over the long term.

And yet, the question of institutional change was explored early on by certain sociologists, who showed that the main challenge for any institution lies in its survival and adaptation to its environment or "ecology" (Hughes 1936). Whether institutions are consolidated and crowned with a form of legitimacy, or whether they evolve outside the realm of respectability and thus find themselves described as "bastard institutions" (Hughes 1996), their development is systematically marked by multiple challenges and difficulties. These concern funding issues as much as museum personnel or visitors. They involve a perpetual adaptation to the different facets of this environment, ${ }^{6}$ even though all of the events that occur do not necessarily affect the institutions, either because they are not of particular relevance, or because they are not significant enough to require finding a solution (Pfeffer and Salancik 1978). Studying institutions is therefore a case of analyzing "how social values and collective arrangements are made and unmade" (Hughes 1996:140). This implies a dynamic perception of change, one that political

scientists have long shared (Laborier and Trom 2003; Lagroye and Offerlé $2010^{7}$ ), and that ethnologists today are taking up again (Monjaret 2005 ${ }^{8}$ ).

Following on from these works, we propose an analysis of the current fate of French ethnology museums, paying particular attention to the institutional mechanisms that require careful structuring - constantly reviewed - between permanence and change, legacy and reorganization; resistance and reinvention. This volume ${ }^{9}$ therefore constitutes a contribution to the analysis of institutional change. But insofar as the analysis focuses on institutions that maintain very close historical ties with the political sphere, it also contributes to the understanding of the phenomena resulting from politicization, understood as the conversion of practices into political activities (Lagroye 2003), by revealing the ramifications and institutional mechanisms that underlie, guide, and constrain this process.

\section{Political Transformations Seen Through the Lens of Institutional Temporalities}

Ethnology museums can be understood as venues for the production and staging of images pertaining to a particular social group, as a reflection of the ways in which a society represents both itself and "others." This explains why the question of "identity" is recurrent here, both from the point of view of the missions undertaken by the museums and the subsequent analyses made. These museums have thus been identified as privileged instruments of representation of the nation and as a mechanism for institutionalizing states. This is notably true of constructivist 
theories, which focus on tracing the progress of construction of nation-states (Anderson [1983] 1996; Gellner 1983; Hobsbawm [1990] 1997) and the "creation of national identities" (Hobsbawm and Ranger 1983; Thiesse 1999). Just like newspapers or textbooks (Anderson [1983] 1996; De Cock and Picard 2009), museums are supposed to promote a meeting of the minds between individuals who do not know each other and probably never will. Through such instruments of collective self-representation, these individuals tend to develop a sense of belonging to the same nation (Anderson [1983] 1996), including when identification with the "group" happens at local level, as was demonstrated in Germany (Roth 1990; Charléty 2001, 2005). ${ }^{10}$

Despite the criticism leveled at such views, we wish to emphasize here the temporal shortcomings of these approaches, for while they have the merit of mentioning the close links that exist between museums, politics, and science (Benoit 2008), they tend to neglect this dimension. ${ }^{11}$ We believe that this relative lack of attention to the subject of the dynamics of change can be partly explained by the fact that constructivist approaches initially understood ethnology museums - and the underlying craze for folklore - in the same register as other elements of the identity "check-list" (language, flag, music, food, etc.), ${ }^{12}$ and not as "institutions" in their own right. And yet, subject as they are to fluctuations in science and politics, these representations and the institutions that convey and portray them change spatially and over time. Both stable and changing, these museums thus constitute a special instrument for measuring evolutions in society, a genuine "seismograph" (Mazé 2009) of the way in which societies see and think of themselves and others.

\section{Institutional Cycles}

Insofar as ethnology museums are supposed to embody, in part, the image that certain groups or representatives of communities aspire to give of themselves, any change affecting society will have potential repercussions on these institutions. To put forward this hypothesis of common sense is to adopt a dynamic view of change and encourages not confining the analysis to a specific moment in the history of these institutions, namely the most critical. Taking the longterm evolution of these museums as the subject of our analysis, the main interest of the contributions in this volume lies in highlighting the motivations behind institutional change. Indeed, all of them reveal the intertwined character of structural factors (political, economic, and scientific), while pointing out the highly contingent dimension of certain events, which explains why a project is sometimes accelerated and sometimes temporarily or even definitively called into question. An example of the former involves the presence of the National Front in the second round of the French presidential elections of 2002, a situation that constituted a favorable environment for the development of the Cité Nationale de l'Histoire de l'Immigration (CNHI, the National Museum of Immigration History), which consequently benefitted from the support of President Jacques Chirac (•Monjaret and Roustan 2013). ${ }^{13}$ The Musée des Civilisations de l'Europe et de la Méditerranée (MuCEM, Museum of European and Mediterranean Civilisations) is a perfect example of the opposite scenario, successively undergoing the collateral effects of the General Review of Public Policies (Révision Générale des Politiques Publiques, RGPP) and competition from the America's Cup that the city of Marseille was then hoping to host (•Mazé 2013). Different institutional phases punctuate the lives of these museums, resulting from a 
subtle blend of transformations over the long term and factors related to the economic climate, promoting the phenomena of rupture and acceleration. This principle is as much at work in a national museum like the Musée National des Arts et Traditions Populaires (MNATP) (• Segalen 2013), as in a museum operating on a more modest scale, such as the Saint-Nazaire ecomuseum (• Chaumier 2013). ${ }^{14}$ It can be understood in the image these institutions project, namely their scenography and design, each stage being accompanied by its own museographic options and constraints $(\bullet$ Chaumier 2013; •Ventura 2013b).

These different phases, which are often accompanied by a reinterpretation of the collectionsboth as regards the meaning given to them and their administrative management - clearly show that heritage is anything but static. But because evolutions are not linear, steps backwards being witnessed, the changes taking place are better described by the notion of "cycles." This is the term preferred by Fabrice Grognet in reference to the Musée de l'Homme in Paris, whose longterm history reveals that the current institutional approach is similar to that of one hundred thirty years ago, combining both cultural production and natural history. While making their presence felt in the successive arrangements of discourse produced by institutions, as in the case of the Quai Branly Museum (MQB) (•Ventura 2013b), these reiterations of the past can also be influenced by the materiality of the buildings housing the institutions. This is clearly shown by the strong architectural constraints in the Palais de la Porte Dorée exhibition hall in Paris, which formerly housed the Museum of the Colonies. The colonial symbolism of the décor, which is equally present in the social and activist uses the Palais inspires (from the Surrealist Manifesto of 1931 to the occupation by undocumented immigrant workers in 2010), explains the difficulties in adapting and reorganizing this venue (•Monjaret and Roustan 2013). It thus provides a particularly interesting and unusual example of the path dependence ${ }^{15}$ phenomenon, which explains how the weight of past decisions often influences those taken in the present, limiting institutional options (North 1990).

But cycles specific to one institution cannot be separated from the overall dynamics faced by thematically similar museums, especially in the same region. While revealing that the exercise consisting in representing France is practiced with the greatest success at local level, and not in Paris, the arrival of agriculture in museums cannot be understood without reference to the profound upheavals that the rural world underwent during the 20th century ( $\bullet$ Dupuis 2013). ${ }^{16}$ This general movement takes different forms depending on local specificities. Nowhere is this more obvious than in the industrial regions. In the Nord-Pas-de-Calais (•Melin 2013), three periods seem to have thus marked the institutional dynamics. The first saw the mobilization of local actors and private initiatives in the development and promotion of industrial heritage. The second was marked by the politicization of these initiatives by the public authorities and notably the Regional Council. Finally, the third period, as yet unfinished, seems to focus on major art museums, judged more likely to meet the requirements of the international cultural influence of the region, which has been intensifying since the Lille 2004 cultural project. Similar regional dynamics are at work in Picardy, also in the north of France $(\bullet$ Hertzog 2013), which is experiencing a loss of interest in its formerly popular rural museums. This temptation to refer today to another history is largely due to changes at regional levels and to the concern, for Picardy, of repositioning the region at European level. From this point of view, museums that develop and enhance industrial heritage seem to be spared more than others because, in the 
opinion of the political decision makers, they are more in phase with restructuring and "local development" strategies.

\section{Temporal Dissonance}

While institutional changes are closely linked to changes affecting society, their rhythms are not necessarily similar. Ethnology museums remind us of the fact that institutions sometimes respond less quickly to changes that affect their environment. There are many reasons for this, the main one lying in the frequent gap between scientific and political temporalities, the French government of the late 1930s, for example, finding a political and social interest in the creation of the Musée de l'Homme where no interest was found in 1878 (Grognet 2015). Thus, fluctuations in political messages upset the structure of museums in society ( $\bullet$ Ventura $2013 b)$, such shifts being likely to arise over a very short period due to a specific economic context. A case in point is the Saint-Nazaire ecomuseum, which the town councilors refused to officially inaugurate because its opening coincided with the crisis affecting the local shipbuilding industry $(\bullet$ Chaumier 2013).

Temporal dissonance not only arises from being out of step with politics, but also with broader societal changes. One of the main factors is the strong architectural constraints placed on museums due to their wide variety of collections, as well as exhibition and conservation requirements, which necessitate the laying out of specific areas that are difficult to standardize. ${ }^{17}$ When the MNATP opened in the early 1970s, it was already very much out of step with the spectacular changes in rural society at that time. While concerns for the environment and the preservation of agricultural machines were replacing interest in know-how, at regional level, popular cultures largely shifted to the side of the factories and the industrial world, which the new museum was rather at a loss to take into account (•Dupuis 2013; $\bullet$ Segalen 2013).

Finally, another explanation, which continues on from the previous one, concerns the constraints related to the materiality of museum collections and approaches, which tend to freeze representations over the long term, despite efforts on the part of the institution to renew its position ( Ventura 2013b). Even though the very fact of collecting objects irreparably turns the museum towards the past and away from future prospects ( $\bullet$ Chaumier 2013 ), the reinterpretation of collections acquired in reference to a specific period and space is often seen as attempting the impossible, as evidenced by the European and contemporary dimension of collections of art and folk traditions ( Mazé 2013; • Segalen 2013). For all these reasons, an alternative seems to be sought today through the growing importance of temporary exhibition spaces and the recourse to new museographic forms $(\bullet$ Chaumier 2013).

\section{Actors of Institutional Change: The Growing Influence of Politics}

The dynamic evolution of institutions being the result of diverse maneuvers on the part of social actors (Pfeffer and Salancik 1978), it is generally advisable to identify the "relevant environment" of an institution (Crozier and Friedberg 1977) by finding out exactly who is mobilized around the narrowest and most active core of individuals (Hughes 1996). Ethnology 
museums being extremely sensitive to environmental, political, and scientific fluctuations, the role of elected officials and the scientific staff of these institutions, as well as their relationships, should be analyzed more closely. While providing a further scale of analysis to understand the dynamics of change, this perspective allows for better identifying the uniqueness of these museums, responsible for defining the geographical, economic, and social area, but also for perpetuating the history of the nation and its regions by representing the historical past and political ambitions. Their social role is indeed doubled with political prerogatives that come to define or even transform it depending on the expectations of the moment.

\section{Elected Officials and the Symbolic Benefits of Museums}

The predominant role of the government and public authorities in supporting cultural institutions is today well attested. Since the 1980s, this support, which goes beyond partisan divisions, has resulted in a form of depoliticization in favor of an increasingly recognized managerial dimension. This can be partly explained by the growing role of professionals and technicians, as well as the strong budgetary constraints that cultural institutions and public authorities are forced to deal with (Dubois 1999). Today, however, we are witnessing an evolution in the modes of politicization of culture, which seem to be characterized by a loss of prerogative on the part of cultural actors to the benefit of elected officials, a trend partly favored by the generalization of an economic view of culture and sometimes encouraged by budget cuts (Dubois et al 2012).

While recalling that certain cultural institutions are historically more open to politicization undertakings, the contributions in this volume confirm the theory of a return of politics in cultural affairs. They also shed light on the motivations of political decision makers in the support given to these cultural institutions, which appear as much as tools for the transmission of knowledge as for communication and political legitimacy. ${ }^{18}$ This phenomenon is not fundamentally new, museums having always maintained close ties with ventures involved in political glorification (Poulot 2008). ${ }^{19}$ Thus, for example, from the Popular Front period on, politics quickly saw in rural museums a way to strengthen the sense of belonging of farmers to the nation, these institutions being considered as an effective way to conquer the rural electorate ( Dupuis 2013). National museums have also experienced a reconfiguration of their social role, being constantly directed and determined by the political message, the assertion of which sometimes permanently seals the fate of the museum. This was the case of the Palais de la Porte Dorée, constructed for the Paris Colonial Exposition of 1931 and celebrated as a witness for posterity (•Monjaret and Roustan 2013). The philosophical purpose of the Musée de l'Homme (Grognet 2015), designed as a political, social and anti-racist tool under the Popular Front, thus continues today to be affected by the new political concerns of the State, incorporating ecological and environmental questions.

While this political investment exists of old, it nevertheless seems to have developed on an unprecedented scale over the last decade, given that it now affects all of the national museums. The Quai Branly Museum, for example, shapes its discourse on France's foreign policy, reiterating the "cultural dialogue" imperative promoted by Jacques Chirac ( Ventura 2013b), in line with the priorities set by UNESCO. As for the CNHI, it is attached to the controversial Ministry of Immigration, Integration, National Identity and Co-development. Because it 
represents an unprecedented operation as much as an ideological trap (Bazin, Gibb, and Selim 2007), this connection profoundly affects the institution. It notably resulted in the resignation of some of the scientists and historians involved in promoting the museum. It also explains the absence of a proper inauguration ( Monjaret and Roustan 2013) and, subsequently, that of sufficient budgetary resources. Finally, while being affected by the notion of "cultural diversity," established as a new paradigm of public policies in the field of culture (Angelo 2002; Négrier 2008), the recent refocusing of the MuCEM on the Mediterranean can also be explained by its expected contribution to the Union for the Mediterranean multilateral partnership project, initiated by former French President Nicolas Sarkozy (•Mazé 2013).

Local authorities are not to be outdone either, although the phenomenon is less visible due to the often smaller size of the museums, which therefore receive less media coverage. After a period of disinterest in private initiatives, representatives of the Nord-Pas-de-Calais region decided to support technical museums, instrumentalizing the disinterest of the State for industrial culture in order to enhance their political legitimacy by drawing on the identity-based demands of local clubs and societies. They have therefore been responsible for transposing onto the cultural scene local discontent with the State and employers for failing to preserve jobs in the industrial sector ( Melin 2013). While sharing the same concern of breaking with the negative image of the region within a context of economic crisis, Picardy is yet another region that testifies to the role of ethnology museums in political clashes between the different levels. Following its administrative construction during the 1960s, the desire for the unified development of the region emerged among the elected officials, while the State was tempted to break it up by incorporating it into the Ile-de-France region. It is within this context that the General Council of the Somme opened the Museum of Rural Life as a response to these political stakes (• Hertzog 2013). ${ }^{20}$ Like historical pageants (Martin and Suaud 1996), and because they allow local officials to embody a region, these ethnology museums therefore constitute an important tool in the process of political legitimation, closely linked to the feeling of "roots," of "settling" in a place, and the symbolic staging of this affiliation (Abélès 1989).

\section{Museum Directors and Their Role as Interface: Towards Greater Politicization ${ }^{21}$}

The involvement of elected officials in the running of these museums directly questions their relationships with those responsible for these institutions, especially the role of interface of museum directors, whose entrepreneurial character-with the significant part of relations with trusteeships that this comprises - has been highlighted (Poulard 2010). The contributions making up this volume point out that the ability of museum directors to deal with the political environment is sometimes formerly attested, as in the case of museologist Georges-Henri Rivière, who managed to promote his museum project by negotiating with such very different governments, from an ideological point of view, as the Popular Front and Vichy France ( $\bullet$ Segalen 2013). While historically such relationships are sometimes compromised due to misalignments of interest between the scientific and political worlds (Grognet 2015), the contemporary period seems to be characterized by significant changes. At national level, the ties thus seem to have become stronger in recent years between political decision makers and museum directors, to the point that we can wonder whether "functional politicization," based on the search for adherence on the part of officials to the direction taken by the management of 
public affairs, does not lose ground to "partisan politicization," which sees the priority given to the party apparatus and its members, or even its supporters. ${ }^{22}$ Thus, the unprecedented involvement of politics in the scientific and cultural content of museums is accompanied by the appointment of trustworthy administrators, often graduates of the École Nationale d'Administration (ENA, the National School of Administration) (Grognet 2015; - Ventura 2013b; -Mazé 2013). While these examples fall within a broader trend concerning the substitution of administrators in the place of curators at the head of the major national museums (Poulard 2007), the "scientific" staff of these museums are no less affected by these political affiliations. This is evidenced by the close relationships that curator Michel Colardelle maintained with the Socialist Party throughout his career, and which played a role in the project to convert the MNATP into the MuCEM, both locally and nationally, before Colardelle was replaced for political reasons (•Mazé 2013). But these political relationships can also be found on the side of researchers, appealed to by the Socialist Party to amend certain right-wing projects. This was the case with the appointment of Maurice Godelier at the head of the scientific program of the Musée des Arts Premiers (Museum of Indigenous Art) project ( Ventura 2013b), a decision that originated in a private conversation with Claude Allègre before he was appointed Minister of Education and Research, following the dissolution of the National Assembly in 1997 by Jacques Chirac and the return to power of a left-wing government (Ventura 2006). This scenario is reminiscent of the appeal made by the Socialist Party to Madeleine Rebérioux, known for her political commitments (Fridenson 2007), in order to redirect the Musée d'Orsay project initiated by President Valéry Giscard d'Estaing in 1977 (Poulard 2010). It raises the wider issue of the reappropriation of politics by actors in the cultural sector, which we can assume is encouraged by the overall context of budget cuts and increased competition between institutions.

\section{The "Venue" of Institutional Change, or Ethnology Museums as a System of Relationships}

A detailed understanding of institutional dynamics requires measuring the importance of "interorganizational" relations, institutions being inserted within an environment that includes other institutions with which they are required to negotiate (Pfeffer and Salancik 1978).

From that point on, any change affecting one institution is likely to have repercussions on the others, whether the latter offer the same product or service, or whether they constitute another link in what might be called a "chain of cooperation" (Becker 1988), to take only these examples. This principle, which is present in an unequal way depending on the type of institutions or environments concerned, is particularly acute in the case of ethnology museums. This can be explained both by the presence of collections, which are never permanently affiliated with one institution and therefore likely to be reallocated to another, as by the pre-eminent role assigned to these museums in the production of the social image of a nation, region, or community, a mission that makes them extremely sensitive to the political climate, as we observed above. Replacing the analysis of museums in this overall dynamic allows for avoiding the pitfalls of certain monographic approaches while also refuting the "crisis" paradigm and providing a better understanding of the institutional contingencies inherent in all processes of politicization. 


\section{Institutional Survival: The Tension Between Imitation and Distinction}

Even though the institutional environment results in a pressure to conform and explains certain phenomena of imitation (DiMaggio and Powell 1983), multiple strategies are deployed by the institutions. These strategies are an attempt to control external sources of uncertainty in order to gain more autonomy and to pursue certain interests (Crozier and Friedberg 1977), negotiating their position within these constraints (Pfeffer and Salancik 1978). Ethnology museums offer a perfect illustration of the contradictory imperatives facing many institutions, between imitation and the search for originality. For example, even though they struggle or fail to account for the contemporary changes in our society, several national museums seem tempted today to offer a forum for "works of art" and to have recourse to contemporary artistic creation (Mazé 2010), a scientifically simpler bias that sometimes betrays an attempt to erase an embarrassing colonial legacy ( Monjaret and Roustan 2013). However, the mutual attention on the part of these institutions not only results in a process of imitation. Museums also seek to distinguish themselves from others, especially when certain institutional options have initially met with failure. This is why the new Quai Branly Museum decided to distance itself from the "laboratory-museum" model of the Musée de l'Homme and the MNATP, cohabitation between curators and researchers being recognized today as one of the causes of the difficulties encountered by these institutions (•Ventura 2013b). It is also this same diagnosis that is currently leading the MuCEM to break with this legacy. But these two processes of homogenization and individualization can be at work simultaneously, as paradoxical as this may seem. A good example of this is the MuCEM. While the redefinition of the MNATP reflected an opening up of the nation's museum to Europe, the interest demonstrated for the Mediterranean represents, at the same time, a valuable means of distinction within this context of competition between European projects. Equally significant is the creation of a "Network of European Museums," which reflects the concern of different promoters to keep abreast of advances made by their counterparts, while allowing each of them to find and claim its own specificity, the creation of this network being guided by the search for a subtle balance between conformity and differentiation (•Mazé 2013).

This dual movement is clearly visible at a regional level, a testimony to the rapid spread of types of museums during certain periods, while presenting significant differences, partly determined by the specificity of the locations (rural areas, vacant industrial land, working-class neighborhoods) and the traditions and know-how developed there $(\bullet$ Hertzog 2013; • Melin 2013). Despite phenomena attesting to the collective popularity of certain forms of heritage, this injunction to diversity is also prompted by regional authorities that, like in the Nord-Pas-deCalais, show their commitment to establishing a network of these museums in order to strengthen coherence between the different venues while streamlining the granting of public subsidies ( $\bullet$ Melin 2013). Added to this is the ambivalent nature of some management tools, such as the Scientific and Cultural Project. This project is of a clearly normative nature, since it comes with the pressure to conform and contributes to the imitation between institutions, encouraging museums to adjust to the administrative criteria that define the obtaining of public subsidies. But at the same time it contributes to this regional diversity, insofar as it also invites these museums (and this at least represents a guarantee of survival for many institutions) to reposition their collections around new issues, thereby justifying their individuality and legitimacy $(\bullet$ Hertzog 2013). Finally, we should not forget that this regional diversity is sometimes encouraged by the 
competition between public authorities. For example, the current policy of the Regional Council of the Nord-Pas-de-Calais is in favor of setting up branches of major national art museums (•Melin 2013), which is not without calling into question the future financing capacity of these institutions. This seems to support the General Council of the Nord department in its decision to promote an alternative policy, focused on providing support to small ethnology museums within the framework of a cross-border network of partnerships and institutional support.

\section{Institutional Competition and Hegemonic Strategies}

Of course, the processes of "inter-organizational" influence cannot be reduced to a peaceful and harmonious coexistence. They are also marked by struggles: the number of institutions attempting to take control over others is high, the concentration of power unequal, and exchanges asymmetrical (Pfeffer and Salancik 1978). In fact, institutional strategies involve both adaptation to the environment and an attempt to transform it (Pfeffer and Salancik 1978).

The landscape of national museums in France is particularly revealing of these institutional struggles, competition and the balance of power between institutions having reached an unprecedented scale over the past decade. At national level, the dominant position acquired by the Quai Branly Museum has been at the expense of other institutions, resulting in relatively unequal institutional adjustments. ${ }^{23}$ This hegemony manifests itself at two levels. Firstly, where discourse and symbolism are concerned, the adoption and imposition of an aesthetic view of the objects makes it possible to liken the concept of "indigenous arts" to a rhetorical takeover. ${ }^{24}$ While the ensuing debate, notably with anthropologists, serves only to tense the positions, or indeed caricatures (Ventura 2013a), the concept is not any less performative inasmuch as it finds a concrete expression on the museographic scene (•Ventura 2013b). For the second level does indeed refer to the materiality of the collections and venues, the hegemonic position of the Quai Branly Museum having concrete effects on the redefinition of the institutions, their content and their staff. ${ }^{25}$ Indeed, its development led to the closure of the Musée National des Arts d'Afrique et d'Océanie (MAAO, Museum of Arts of Africa and Oceania) located in the Palais de la Porte Dorée (Anne Monjaret and Mélanie Roustan), as well as an inevitable redefinition of the Musée de l'Homme (Grognet 2015) to the benefit of the MuCEM, which acquired some of the former's collections, thus ensuring its own development (•Mazé 2013). What we are witnessing is therefore truly a case of institutional struggles: this redefinition raises controversy and resistance, resulting in resignations, transfers, and new appointments as all of the articles concerning the national museums clearly show.

While these dynamics are particularly recognized on the Parisian scene, they are obviously not specific to state institutions, being inevitably also found at local level. This is evidenced, for example, by the evolution of the Saint-Nazaire ecomuseum, which is struggling to provide the economic benefits expected by the town officials ( $\bullet$ Chaumier 2013). The result is the emergence of a new tourism structure, which has rapidly emancipated itself from the ecomuseum where it initially originated, while still drawing on some of its collections. This scenario is also symptomatic of the institutional competition that exists at regional level and that allows for understanding regional approaches. Given the perspective offered by the scale of analysis used, the cases of Picardy ( $\bullet$ Hertzog 2013) and the Nord-Pas-de-Calais (•Melin 2013) indeed suggest 
that when the complementarity of regional museums is weak and the thematic specificities less obvious, then competition and power struggles are greater and the longevity of some institutions more uncertain. In other words, the most consistent and similar museums, namely those with collections of popular arts and traditions, are more institutionally fragile because they are less likely to find long-term justification in the eyes of the public authorities, the latter being more concerned with enhancing regional specificities in an attempt to ensure the tourist attractiveness of their constituencies.

These evolutions suggest that, despite their individualities and specific anchoring points, ethnology museums face common problems, revealing the absolute need to think of them as a whole and to make their interactions clear over the long term. To situate them within this system of relations allows for breaking with detailed writings and so to better understand the profound nature of the changes and challenges that they face. ${ }^{26}$

\section{Notes}

In producing this translation, Museum Anthropology Review has preserved the introduction's original citation format. References are included in this notes section but also given inline in the body of the text.

1. Besides museums (Clair 2007; Vital 2011; Jenkins 2011), many other institutions devoted to instruction, control, or supervision are also considered to be "in crisis." This view sometimes echoes the recurring complaints and fears with regard to the deterioration of the present, based on the belief in the moral decay of society and contributing to the nostalgia for the "old way of life," perceived and presented as a golden age (Pearson 1983).

2. See for example Emmanuel de Roux 2001. "Le musée de l'Homme est en crise, sur fond de 'guerre civile."' Le Monde. December 13.

3. "Faut-il brûler les musées d'ethnologie?" Gradhiva 1998; "Que faire d'un musée national et que faire dans un musée de la recherche contemporaine?" Le Débat 1991; "Les musées sont-ils anthropologiquement bons à penser?” Le Débat 1992.

4. As we have previously had the opportunity of justifying (Bense, Alves, and Poulard 2007), we choose here to use the concept of "institution" in the sense given by Everett C. Hughes (1996), that of "collective enterprise." While this definition refers to a broad acceptance of institutions, generally preferred in sociology (Durkheim [1895] 1992), anthropology (Douglas [1986] 1999), or political science (Lagroye and Offerlé 2011), we should specify that the case of ethnology museums leads us to examine relatively formalized institutions.

5. This is evidenced by the special issues of certain journals, such as Gradhiva ("Faut-il brûler les musées d'ethnographie?" 1998), Ethnologie française ("Musée nation. Après les colonies," 29(3) 1999; "L'Europe et ses ethnologues," 38(4) 2008), Ethnologies ("Musées d'ethnologie: nouveaux défis, nouveaux terrains," vol. 24 2002). It should be noted that the reflection concerning history museums is expressed from a very similar perspective, as evidenced by the 
two volumes edited by Laurent Gervereau and published by the International Association of Museums of History (What are the perspectives for History museums in Europe? 1997; What is the future of history museums? 1999), as well as the recent work under the direction of JeanPierre Babelon, Isabelle Backouche, Vincent Duclert and Ariane James-Sarazin (Quel musée d'histoire pour la France? 2011).

6. While this issue constitutes a heuristic framework for the analysis of such formal institutions as ethnology museums, its scope is less obvious when the discourse broaches broader social arrangements. Indeed, because the concept of institution remains vague and polysemous, a certain difficulty often persists in delineating the boundaries, as well as a risk of artificially limiting the object of study (Tournay 2011).

7. As recalled by the authors, since the 1970 s several works on political institutions have analyzed the genesis of said institutions, the processes of institutionalization, and the interplay between permanence and change.

8. Recent research has focused on "closures," as evidenced by the special issue of the journal Ethnologie française, entitled "Fermetures. Crises et reprises," as well as the introductory article by Anne Monjaret, for whom closures are not only synonymous with destruction and disappearance, but also jointly refer to the idea of reconstruction, renovation, and innovation (2005:583).

9. Thoughout this paper, references to "this volume" refer to the edited book, Les musées d'ethnologie: culture, politique et changement institutionnel, for which it originally served as the French language introduction.

10. Different national traditions do, of course, exist. France, for example, is different from other European countries in that it was the only country in the 19th century not to create a national museum of folklore and popular culture (Chiva 1993). Indeed, with the French Revolution, this role of representation was vested in the Louvre (Poulot 1997). More recently, since the late 1980s, ethnology museums in Europe have started to develop differently, depending on the countries concerned (Pomian 1996; Mazé 2010).

11. The effectiveness of the identity of ethnology museums has been widely asserted in literature, for the most part a priori, without the desired effect being really called into question (Mazé 2010). These views, in part normative, lend an effective or performative power to cultural and heritage institutions, especially museums, that would be worth exploring further. A critical reading of constructivist theories that question the notion of "identity" (Brubaker 2001) invites us, indirectly, to do just that.

12. To quote Anne-Marie Thiesse (1999).

13. Citations preceded by a diamond refer to chapters in Les musées d'ethnologie: culture, politique et changement institutionnel. 
14. This phenomenon is also discernible through other institutional monographs, such as that of the Le Creusot ecomuseum in Burgundy (Debary 2002).

15. Path dependency theory.

16. This phenomenon is anything but surprising when considering the emphasis placed on local identities in the celebration of the national identity under the Third Republic (Thiesse 1997).

17. The construction of a museum building therefore takes time, including when it proves necessary to rehabilitate a building that was initially used for a different purpose.

18. From this point of view, ethnology museums present strong similarities with the field of archaeology, highly influenced by various forms of nationalism and political strategies (Kohl and Fawcett 1995).

19. As recalled by Jacques Lagroye (2003:367), the interest of political actors for the politicization of social activities, practices or mobilizations, as well as the expected resources (in election campaigns, conflicts with rivals, etc.), are today well documented.

20. These two cases are somewhat reminiscent of the initial reluctance of the French government with respect to the ambition of Departmental Conservation Departments to become instruments to promote the region. An example is the creation in 1992 of the Departmental Conservation Department of the General Council of the Isère, initially frowned upon by the national authorities. The elected officials had wanted to extend the powers of the General Council in all areas of heritage (ethnology, archaeology, and inventory), based on the experience gained by the Musée dauphinois county museum, the latter being distinguished by its role at the head of a network involved in the conservation and development of the heritage of twelve small museums scattered throughout the department (Guibal 1996).

21. We refer here to a more restrictive acceptance of politicization, namely the examination of methods of political control.

22. Here we take up the distinction put forward by Stéphane Dion (1986) on the basis of his study of how municipalities work. The phenomenon of the "politicization" of officials can be partly explained by the legislative uncertainty surrounding the definition of the roles of elected officials and administrative officers, the forms of interpenetration between the political and administrative sectors also being witnessed in the upper echelons of the government (Baecque and Quermonne 1981).

23. Some authors have begun to highlight the close relationship between the different national museums, citing for example the "renegotiation of status and meaning" caused by the closure of the MAAO (Eidelman et al 2005:605).

24. As Marc Abélès (1999) points out, words are related to categories that feed the debate both inside and outside the institutions, their impact resulting from the connotations they evoke in the public imagination. 
25. From this point of view, ethnology museums provide a valuable record of the redevelopment of the objectives and activities induced by any process of politicization, as well as their real impact on the practices and principles of legitimation (Lagroye 2003:370).

26. In the original French version of this introduction, four paragraphs mapped out the subject matter covered in the book Les musées d'ethnologie: culture, politique et changement institutionnel. Those paragraphs are omitted here.

\section{References Cited}

Abélès, Marc

1989 Jours tranquilles en 89: Ethnologie politique d'un département français. Paris: Odile Jacob.

1999 Pour une exploration des sémantiques institutionnelles. Ethnologie française 29(4):501511.

Anderson, Benedict

1996 [1983] L'imaginaire national. Réflexions sur l'origine et l'essor du nationalism. Paris: La découverte.

Angelo, Mario

2002 Diversité culturelle et dialogue des civilisations: l'évolution des concepts de 1990 à 2001. Paris: Idée Europe.

Babelon, Jean-Pierre, Isabelle Backouche, Vincent Duclert, and Ariane James-Sarazin, dir.

2011 Quel musée d'histoire pour la France? Paris: Armand Colin.

Baecque, Francis de and Jean-Louis Quermonne, dir.

1981 Administration et politique sous la cinquième République. Paris: Presses de la fondation nationale des sciences politiques.

Baumann, Zygmut

2006 La Vie liquid. Paris: Le Rouergue/Chambon.

Bazin, Laurent, Robert Gibb, and Monique Selim

2007 Nationalisation et étatisation des identités dans le monde contemporain. Journal des anthropologues. Hors série:7-35. 
Becker, Howard

1988 Les Mondes de l'Art. Paris: Flammarion.

Benoit, Isabelle

2002 Politique de mémoire: les musées d'histoire français et allemands 1945-1995. PhD diss., IEP de Grenoble.

2008 Repenser les musées de la nation. Le musée de l'Europe. In De nouveaux modèles de musées? Formes et enjeux des créations et rénovations de musées en Europe 19e-21e siècles. Anne-Solène Rolland and Hanna Murauskaya, dir. Pp. 163-236. Paris: L'Harmattan.

Bense, Ferreira, Célia Alves, and Frédéric Poulard

2007 Le travail dans les institutions culturelles. Sociétés Contemporaines 66:5-16.

Boëll, Denis-Michel, Jacqueline Christophe, and Régis Meyran

2009 Du folklore à l'ethnologie. Paris: Editions de la maison des sciences de l'homme.

Brubaker, Rogers

2001 Au-delà de 1'“identité." Actes de la recherche en sciences sociales 139(3):66-85.

Charléty, Véronique

2001 Figures muséales et changements sociopolitiques: Les musées d'histoire locale à Berlin: Entre invention et conservation. PhD diss., Université de Paris 1.

2005 Itinéraire d'un musée, le Heimatmuseum. Paris: L’Harmattan.

Chaumier, Serge

2003 Des musées en quête d'identité. Écomusée versus technomusée. Paris: L'Harmattan.

2013 Écomusées: structure porteuse de ressources pour l'avenir. L'exemple de l'écomusée de Saint-Nazaire. In Les musées d'ethnologie: culture, politique et changement institutionnel. Camille Mazé, Frédéric Poulard, and Christelle Ventura, eds. Pp. 271-295. Paris: Éditions du Comité des travaux historiques et scientifiques.

Clair, Jean

2007 Malaise dans les musées. Paris: Flammarion. 
Crozier, Michel and Erhard Friedberg

1977 L'acteur et le système. Paris: Seuil.

Davis, Peter

1999 Ecomuseums: A Sense of Place. London: Leicester University Press.

De Cock, Laurence and Emmanuelle Picard, dir.

2009 La fabrique scolaire de l'histoire. Paris: Agone.

Debary, Octave

2002 La fin du Creusot ou l'art d'accommoder les restes. Paris: CTHS.

Dias, Nélia

1991 Le Musée d'ethnographie du Trocadéro (1878-1908). Anthropologie et muséologie en France. Paris: CNRS.

DiMaggio, Paul J. and Walter W. Powell

1983 The Iron Cage Revisited: Institutional, Isomorphism and Collective Rationality in Organizational Fields. American Sociological Review 48(5):147-160. http://www.jstor.org/stable/2095101

Dion, Stéphane

1986 La politisation des mairies. Paris: Economica.

Douglas, Mary

1999 [1986] Comment pensent les institutions. Paris: La Découverte.

Dubet, François

2002 Le déclin de l'Institution. Paris: Seuil.

Dubois Vincent

1999 La politique culturelle: Genèse d'une catégorie d'intervention publique. Paris: Belin.

Dubois, Vincent, Clément Bastien, Audrey Freyermuth, and Kévin Matz 
2012 Le politique, l'artiste et le gestionnaire: (Re)configurations locales et (dé)politisation de la culture. Paris: Editions du Croquant.

Dubuc, Elise

1998 Le futur antérieur du Musée de l’Homme. Gradhiva 24:71-92.

Dupuis, Richard

2013 De l'agriculture dans les musées aux musées d'agriculture de 1920 à 1980. In Les musées d'ethnologie: culture, politique et changement institutionnel. Camille Mazé, Frédéric Poulard, and Christelle Ventura, eds. Pp. 129-154. Paris: Éditions du Comité des travaux historiques et scientifiques.

Durkheim, Emile

1992 [1895] Les règles de la méthode sociologique. Paris: PUF.

Eidelman, Jacqueline, Anne Monjaret, and Mélanie Roustan

2005 Fin du MAAO: Un patrimoine revisité. Ethnologie française 35(4):605-616.

Faure, Christian

1989 Le projet culturel de Vichy. Lyon: Presses universitaires de Lyon-CNRS.

Fridenson, Patrick

2007 Madeleine Rebérioux entre histoire, culture et politique. Le Mouvement Social 2(219220):3-16.

Gellner, Ernest

1999 [1983] Nations et nationalism. Paris: Payot et Rivages.

Gervereau, Laurent, dir.

1997 Quelles perspectives pour les musées d'histoire en Europe? Paris: AIMH.

1999 Quel avenir pour les musées d'histoire? Paris: AIMH.

Grognet, Fabrice

2015 The Metamorphoses of the Trocadéro and the Re-invention of the Musée de l'Homme. Museum Anthropology Review 9(1-2):58-79. http://dx.doi.org/10.14434/mar.v9i1$\underline{2.12943}$ 
Guibal Jean

1996 Les musées de "société” à la recherche de leur devenir. In Musées gérer autrement: Un regard international. Jean-Michel Tobelem, dir. Pp. 283-291. Paris: La Documentation française.

Hainard, Jacques and Roland Kaehr, dir.

1985 Temps perdu. Temps retrouvé. Voir les choses du passé au present. Neuchâtel: Musée ethnographique de Neuchâtel.

Héritier-Augé, Françoise, dir.

1991 Les musées de l'éducation nationale, Mission d'étude et de réflexion, rapport au ministre d'État, ministre de l'éducation nationale. Paris: La Documentation française.

Hertzog, Anne

2013 Les musées d'ethnologie au défi des recompositions territoriales Le cas des musées consacrés à la ruralité en Picardie. In Les musées d'ethnologie: culture, politique et changement institutionnel. Camille Mazé, Frédéric Poulard, and Christelle Ventura, eds. Pp. 241-270. Paris: Éditions du Comité des travaux historiques et scientifiques.

Hobsbawm, Eric and Terence Ranger

1983 The Invention of Tradition. Cambridge: Cambridge University Press.

Hobsbawm, Eric

1997 [1990] Nations et nationalismes, depuis 1780: programme, mythe, réalité. Paris: Gallimard, Folio Histoire.

Hughes, Everett C.

1936 The Ecological Aspect of Institutions. American Sociological Review 1(2):180-189. http://www.jstor.org/stable/2084476

1996 Le regard sociologique: Essais choisis, textes rassemblés et présentés par Jean-Michel Chapoulie. Paris: EHESS.

Jamin, Jean

1998 Faut-il brûler les musées d'ethnographie? Gradhiva 24:65-69.

Jenkins, Tiffany 
2011 Contesting Human Remains in Museum Collections: The Crisis of Cultural Authority. New York: Routledge.

Kohl, Philip and Clare Fawcett, eds.

1995 Nationalism, Politics, and the Practice of Archaeology. Cambridge: Cambridge University Press.

L'Estoile, Benoît de

2007 Le goût des Autres. De l'Exposition coloniale aux Arts premiers. Paris: Flammarion.

Laborier, Pascale and Danny Trom, dir.

2003 Historicités de l'action publique. Paris: PUF.

Lagroye, Jacques, dir.

2003 La politisation. Paris: Belin.

Lagroye, Jacques and Michel Offerlé

2010 Sociologie de l'institution. Paris: Belin.

Le Menestrel, Sara

1996 La collecte de l'objet contemporain, un défi posé au Musée de la Civilisation à Québec. Ethnologie française 26(1):74-91.

Lebovics, Herman

1995 [1992] La "Vraie France.” Les enjeux de l’identité culturelle 1900-1945. Paris: Belin.

2004 Bringing the Empire Back Home. Durham, NC: Duke University Press.

Martin, Jean-Clément and Charles Suaud

1996 Le Puy du Fou en Vendée: L’Histoire mise en scène. Paris: L’Harmattan.

Mazé, Camille

2009 Les musées de l'Europe: Vacillement ou renforcement du modèle du musée national? In Les musées de la nation: créations, transpositions, renouveaux. Anne-Solène Rolland, Mathilde Labbé and Sarah Legrain, eds. Pp. 123-143. Paris: L'Harmattan. 
2010 Mettre l'Europe au musée: une affaire d'État?Ethnographie et sociohistoire du chantier des “musées de l’Europe” (1980-2010). PhD diss., EHESS-ENS.

2013 Du MNATP au(x) MuCEM: Les vicissitudes du muse français d'ethnologie nationale. In Les musées d'ethnologie: culture, politique et changement institutionnel. Camille Mazé, Frédéric Poulard, and Christelle Ventura, eds. Pp. 177-204. Paris: Éditions du Comité des travaux historiques et scientifiques.

Melin, Hélène

2013 Le rôle des musées de patrimoine industriel dans les reconversions territoriales: Le cas de la Région Nord-Pas-de-Calais In Les musées d'ethnologie: culture, politique et changement institutionnel. Camille Mazé, Frédéric Poulard, and Christelle Ventura, eds. Pp. 207-240. Paris: Éditions du Comité des travaux historiques et scientifiques.

Monjaret, Anne

2005 Quand les lieux de travail ferment... Ethnologie française 35(4):581-592.

Monjaret, Anne and Mélanie Roustan

2013 La repatrimonialisation du Palais de la porte dorée: du musée des Colonies à la Cité nationale de l'histoire de l'immigration. In Les musées d'ethnologie: culture, politique et changement institutionnel. Camille Mazé, Frédéric Poulard, and Christelle Ventura, eds. Pp. 101-126. Paris: Éditions du Comité des travaux historiques et scientifiques.

Négrier, Emmanuel

2008 La diversité, nouveau paradigme des politiques culturelles? Une comparaison européenne. RIPS [Revista de Investigaciones Políticas y Sociológicas, Universidade de Santiago de Compostela España] 7(1):95-110.

North, Douglas

1990 Institutions, Institutional Change, and Economic Performance. Cambridge: Cambridge University Press.

Pearson, Geoffrey

1983 Hooligan: A History of Respectable Fears. London: Macmillan Press.

Pfeffer, Jeffrey and Gerald Salancik

1978 The External Control of Organizations: A Resource Dependence Perspective. New York: Harper and Row. 


\section{Pomian, Krzysztof}

1996 Les musées d'ethnographie dans l'Europe d'aujourd'hui. In Rencontres européennes des musées d'ethnographie. Actes des premières rencontres des musées d'ethnographie 1993. Pp. 37-48. Paris: Musée national des Arts et Traditions populaires - École du Louvre.

Poulard, Frédéric

2007 Diriger les musées et administrer la culture. Sociétés contemporaines 66:61-78.

2010 Conservateurs de musées et politiques culturelles. L'impulsion territorial. Paris: La documentation française.

1997 Musée nation patrimoine 1789-1815. Paris: Gallimard.

2008 Gloires et opprobres politiques au musée. Sociétés et representations 26:197-217.

Querrien, Max

1982 Pour une nouvelle politique du patrimoine. Rapport au ministre de la Culture. Paris: La Documentation française.

Rogan, Bjarne

2003 Towards a Post-colonial and a Post-national Museum: The Transformation of the French Museum Landscape. Ethnologia Europaea 33(1):37-50.

Roth, Marin

1990 Heimatmuseum: Zur Geschichte einer deutschen Institution. Berlin: Gebr. Mann Verlag.

Scott, Richard

2008 Institutions and Organizations: Ideas and Interests. Los Angeles: Sage Publications.

Segalen, Martine

1993 Les ressources humaines: 1'ethnologie. In Musées et sociétés, Actes du colloque national musées et sociétés, Mulhouse-Ungersheim. Pp. 166-168. Juin 1991. Paris: DMF.

2005 Vie d'un musée 1937-2005. Paris: Stock.

2013 L'impossible musée des cultures de la France. Le cas du musée national des Arts et Traditions populaires. In Les musées d'ethnologie: culture, politique et changement institutionnel. Camille Mazé, Frédéric Poulard, and Christelle Ventura, eds. Pp.155-175. Paris: Éditions du Comité des travaux historiques et scientifiques. 
Thiesse, Anne-Marie

1997 Ils apprenaient la France. L'exaltation des régions dans le discours patriotique. Paris: Editions de la Maison des sciences de l'homme.

1999 La création des identités nationales, Europe XVIIIe -XXe siècles. Paris: Le Seuil.

Tournay, Virginie

2011 Sociologie des institutions. Paris: PUF, coll. “Que sais-je?”

Ventura, Christelle

2006 La fondation du Musée du Quai Branly. Matériaux pour une anthropologie politique et culturelle d'une institution. PhD diss., Paris: EHESS.

2013a Partition et répartition. Les corps professionnels et leurs activités au musée du quai Branly. In Les conservateurs et le rôle des personnels scientifiques dans les musées d'aujourd'hui. Frédéric Poulard et Jean-Michel Tobelem, dir. Paris: L'Harmattan.

2013b Les “polyphonies” du musée du quai Branly ou l'art d'acclimater les discours. In Les musées d'ethnologie: culture, politique et changement institutionnel. Camille Mazé, Frédéric Poulard, and Christelle Ventura, eds. Pp. 71-101. Paris: Éditions du Comité des travaux historiques et scientifiques.

Vital, Christophe

2011 Le Livre Blanc des Musées de France. Rapport rédigé au nom de l'Association Générale des Conservateurs des Collections Publiques de France (AGCCPF).

Wahnich, Sophie, dir.

2002 Fictions d'Europe, la guerre au musée, Allemagne, France, Grande-Bretagne. Paris: Editions des Archives contemporaines.

Camille Mazé is Vice President of the Department of Ethnology at the Universite de Bretagne Occidentale.

Frédéric Poulard is an Assistant Professor at the Centre Lillois d'Etudes et de Recherches Sociologiques et Economiques and the Vice Dean of the Economics and Social Sciences Faculty.

Christelle Ventura is associated with the Laboratoire d'Anthropologie et d'Histoire de l'Institution de la Culture at L'École des Hautes Etudes en Sciences Sociales. 
Museum Anthropology Review 9(1-2) Spring-Fall 2015

http://dx.doi.org/10.14434/mar.v9i1-2.19966 